\title{
Potensi kerugian ekonomi akibat biaya rawat inap dan rawat jalan pada balita obesitas yang diprediksi mengalami obesitas saat dewasa di Indonesia
}

Economic losses potential due to cost of inpatient and outpatient in toddlers who has experienced obesity in to adulthood in Indonesia

\author{
Brigitte Sarah Renyoet $^{1}$, Drajat Martianto ${ }^{1}$, Dadang Sukandar ${ }^{1}$
}

${ }^{1}$ Departemen Gizi Masyarakat, Fakultas Ekologi Manusia Institut Pertanian Bogor

\begin{abstract}
Background: Nutrition and balance food very important for pregnant women so that the growth and fetal development can be optimally. Children excess nutrients will be developed into a child obesity, if not be addressed urgently and left until the children become obese adults will lead to decrease productivity. Objective: To estimate the economic losses potential to obesity on the toddler when adults remain obesity and sick so that issued a maintenance costs (inpatient and outpatient). Method: This was an descriptive study with data processing of a variety of the relevant agencies as well as a secondary data in 2013. Data obtained is calculated using the formula derived from research Pitayatienanan et al. 2014 and correction factor of Guo et al. 2002. Results: Estimation of the economic losses potential due to low productivity is $3.492-8.717$ billion rupiah/year $(0,04-0,10 \%)$ of the total GDP in Indonesia. Conclusion: Economic losses potential due to cost of obesity in Indonesia shows the loss of high enough, especially for a developing countries. In addition to its prevalence of problems that high, loss also influenced by the changes disease patterns, maintenance of costs each disease comorbidities of obesity itself.
\end{abstract}

KEY WORDS: economic losses; toddler obesity; toddlers 0-59 months of age

\begin{abstract}
ABSTRAK
Latar belakang: Makanan bergizi dan seimbang sangat penting bagi ibu hamil sehingga pertumbuhan dan perkembangan janin dapat optimal. Anak kelebihan gizi akan berkembang menjadi anak obesitas jika tidak segera diatasi dan dibiarkan sampai anak menjadi dewasa obesitas yang akan menyebabkan penurunan produktivitas. Tujuan: Melakukan estimasi besar potensi kerugian ekonomi akibat obesitas pada balita yang ketika dewasa tetap obesitas dan sakit sehingga mengeluarkan biaya perawatan (rawat inap dan rawat jalan). Metode: Penelitian deskriptif dengan mengolah data dari berbagai instansi terkait serta merupakan data sekunder tahun 2013. Data yang diperoleh dihitung menggunakan rumus yang berasal dari penelitian Pitayatienanan et al. tahun 2014 dan faktor koreksi dari Guo et al. tahun 2002. Hasil: Potensi kerugian ekonomi secara nasional akibat produktivitas yang rendah mencapai Rp 3.492 miliar - Rp 8.717 miliar atau 0,04\% - 0,10\% dari total PDB Indonesia. Simpulan: Kerugian ekonomi akibat biaya perawatan karena obesitas di Indonesia menunjukan kerugian yang cukup tinggi, terutama untuk suatu negara yang sedang berkembang. Selain karena prevalensi masalah yang tinggi, kerugian juga dipengaruhi oleh perubahan pola penyakit dan biaya perawatan dari setiap penyakit komorbiditas dari obesitas itu sendiri.
\end{abstract}

KATA KUNCI: kerugian ekonomi; balita obesitas; balita usia 0-59 bulan

\section{PENDAHULUAN}

Menurut laporan Landscape Analysis Country Assessment (LACA) sebesar 28,5\% mengalami stunting, 25\% populasi dunia mengalami kelebihan berat badan,
17\% anak prasekolah kekurangan berat badan, dan $40 \%$ wanita usia subur menderita anemia (1). Saat ini, obesitas sudah dialami oleh anak-anak di bawah usia 5 tahun (balita). Pada tahun 2012, diperkirakan 44 juta (6,7\%) dari

Korespondensi: Brigitte Sarah Renyoet, Departemen Gizi Masyarakat, Fakultas Ekologi Manusia Institut Pertanian Bogor, Jl. Lingkar Akademik, Kampus IPB Darmaga, Bogor 16680, e-mail: brigitte.sarah@yahoo.com 
anak-anak balita mengalami kelebihan berat badan atau obesitas di seluruh dunia. Berdasarkan angka terbaru ini, prevalensi global anak kelebihan berat badan dan obesitas telah berkembang dari sekitar 5\% pada tahun 1990 menjadi 7\% pada tahun 2012 (2). Bahkan, lebih dari 2,1 miliar orang ( $\pm 30 \%$ dari total populasi dunia) mengalami kelebihan berat badan atau obesitas (3). Menurut World Health Organization (WHO), prevalensi obesitas pada anak di negara berkembang dan negara miskin telah mengalami peningkatan dalam 10 tahun terakhir. Pada tahun 2015, diperkirakan tingkat kegemukan pada negara-negara tersebut akan mencapai prevalensi 11\%, mendekati prevalensi di negara berpenghasilan menengah atas yang prevalensinya mencapai $12 \%$ (4).

Hal ini didukung oleh data Riset Kesehatan Dasar (Riskesdas) yang menunjukkan bahwa insiden balita gemuk pada tahun 2013 mencapai 11,9\%. Terdapat beberapa provinsi yang memiliki masalah balita gemuk di atas prevalensi nasional yaitu Lampung, Sumatera Selatan, Bengkulu, Papua, dan Riau (5). Angka kejadian obesitas meningkat dengan pesat akibat pola hidup tidak aktif. Energi yang digunakan untuk aktivitas fisik sehari-hari mulai berkurang seiring dengan adanya globalisasi dan akibat dari kemajuan teknologi. Aktivitas fisik yang minimal pada waktu luang seperti menonton televisi dan bermain video games pada anak-anak meningkatkan angka kejadian obesitas (6). Masalah obesitas ini dianggap sebagai salah satu faktor yang dapat meningkatkan prevalensi penyakit tidak menular (PTM) seperti hipertensi, intoleransi glukosa, dan penyakit jantung koroner (aterosklerosis) (7). Obesitas juga memicu peningkatan kadar kolesterol, stroke, dan diabetes mellitus (DM) (8).

Dampak ekonomi obesitas secara global termasuk ke dalam tiga besar masalah sosial akibat manusia itu sendiri yang menghabiskan produk domestik bruto (PDB) dunia sekitar \$2 triliun atau 2,8\%. Obesitas juga mempengaruhi perekonomian karena berkurangnya produktivitas. Di Inggris kerugian mencapai \$5 juta akibat penurunan produktivitas kerja (3). Di Kanada pada tahun 2006, tambahan biaya kesehatan akibat kelebihan berat badan dan obesitas diperkirakan mencapai \$6 miliar dan terdapat tambahan pula sebesar \$5 miliar dari kehilangan produktivitas (9). Di Amerika setiap tahun diperkirakan biaya pengobatan akibat obesitas pada orang dewasa mencapai rata-rata \$2741 (mengacu pada dollar Amerika tahun 2005). Di Australia pada tahun 2005, biaya langsung akibat beban kelebihan berat badan dan obesitas mencapai \$21 miliar per tahun (10). Sementara secara nasional, biaya kesehatan akibat penyakit terkait obesitas pada orang dewasa mencapai \$2097 miliar per tahun (11).

Laporan model simulasi untuk proyek kesehatan dan kemungkinan konsekuensi ekonomi dalam dua dekade berikutnya dari kenaikan prevalensi masalah obesitas di Amerika Serikat dan Inggris, memproyeksikan sebesar 65 juta orang dewasa obesitas di Amerika Serikat dan 11 juta orang dewasa obesitas di Inggris pada tahun 2030, akibatnya menimbulkan tambahan 6 - 8,5 juta kasus diabetes; 5,7 - 7,3 juta kasus penyakit jantung dan stroke; serta 492.000 - 669.000 kasus tambahan kanker. Biaya medis gabungan terkait dengan pengobatan penyakit ini dapat dicegah, diperkirakan meningkat sebesar \$48 - 66 miliar/tahun di Amerika Serikat dan 1,9 - 2 miliar pounds/tahun di Inggris pada tahun 2030 (12). Penelitian lain yang telah mengidentifikasi hasil dari 75 penelitian di seluruh dunia, 11 penelitian yang difokuskan pada kawasan Asia-Pasifik (Taiwan, Cina, Jepang, Australia, dan Selandia Baru). Studi mengenai perkiraan biaya perawatan kesehatan langsung yang berhubungan dengan obesitas ditemukan mulai dari 0,059\% menjadi 0,49\% dari PDB nasional. Biaya langsung tertinggi dihitung dan menunjukkan bahwa pengeluaran tahunan mungkin setinggi US\$ 7,4 miliar setahun di Cina. Proyeksi ini menyimpulkan bahwa belanja langsung dan tidak langsung yang dikeluarkan untuk obesitas dapat melebihi 4,1\% dari PDB suatu negara (13).

Indonesia termasuk salah satu negara berkembang yang sedang mengalami masalah obesitas pada balita. Obesitas meningkatkan risiko PTM sehingga akan mempengaruhi ekonomi individu, rumah tangga maupun negara. Masalah gizi dapat meningkatkan biaya perawatan yang dikeluarkan untuk mengobati penyakit, kematian dini yang tidak diharapkan, dan biaya produktivitas yang hilang karena sakit dan kondisi fisik seseorang. Berdasarkan penelitian-penelitian sebelumnya, masih sedikit penelitian mengenai analisis ekonomi yang dapat mengungkapkan kerugian ekonomi 
akibat masalah gizi khususnya masalah kelebihan gizi yang mengakibatkan obesitas pada balita di Indonesia. Berdasarkan pertimbangan tersebut, peneliti tertarik untuk melakukan penelitian ini dengan tujuan yaitu melakukan estimasi perhitungan kerugian ekonomi akibat biaya rawat inap dan rawat jalan karena masalah obesitas di Indonesia.

\section{BAHAN DAN METODE}

Penelitian ini merupakan penelitian deskriptif yang dilakukan dengan mengolah data dari berbagai instansi terkait serta seluruh data yang diperoleh merupakan data sekunder. Kegiatan penelitian dilakukan di Bogor, Jawa Barat dan dilaksanakan mulai bulan Desember 2015 sampai Maret 2016. Jenis data yang dikumpulkan adalah data sekunder yang diperoleh dari berbagai instansi terkait di Indonesia, seperti Badan Penelitian dan Pengembangan Kesehatan (Riskesdas 2013), Badan Pusat Statistik (BPS), Kementerian Kesehatan RI (Kemenkes RI), serta data lain juga diperoleh dari publikasi jurnal-jurnal internasional. Data yang dikumpulkan berupa karakteristik balita di Indonesia (umur, jenis kelamin, data status gizi atau z-score balita, jumlah balita 0-59 bulan yang obesitas) (5), karakteristik penduduk menurut provinsi (jumlah penduduk balita, jumlah kelahiran, jenis kelamin, dan kelompok umur) $(14,15)$, upah/gaji tenaga kerja (data upah/gaji/pendapatan bersih pekerja menurut provinsi dan lapangan pekerjaan utama) (16).

Penelitian ini tidak menggunakan ethical clearance karena data yang digunakan merupakan data sekunder yang diperoleh dari penelitian dan publikasi instansi lain. Data yang diperoleh akan diolah menggunakan program microsoft excel. Estimasi potensi ekonomi yang hilang akibat obesitas pada balita dengan menggunakan rumus Pitayatienanan et al. hasil penelitian di Thailand (17) sedangkan untuk menghitung jumlah serta prevalensi balita umur 3-5 tahun yang obesitas dengan menggunakan faktor koreksi yang berasal dari penelitian obesitas lainnya (18). Menghitung potensi kerugian ekonomi karena obesitas pada balita membutuhkan faktor koreksi karena tidak semua balita obesitas ketika dewasa nanti tetap mengalami masalah obesitas sehingga penelitian ini menggunakan faktor koreksi untuk menghitung peluang menjadi dewasa obesitas. Lebih lanjut, untuk memperoleh jumlah balita obesitas yang diprediksi obesitas saat dewasa, jumlah balita obesitas laki-laki dan perempuan usia 3-5 tahun (5) dikali dengan faktor koreksi dari persentase probabilitas balita obesitas laki-laki usia 3, 4, dan 5 tahun yang akan menjadi dewasa obesitas yaitu sebesar 0,15\%; 0,14\%; dan 0,31\%. Sementara faktor koreksi untuk balita obesitas perempuan pada usia yang sama yaitu sebesar 0,24\%; 0,25\%; dan 0,37\% akan menjadi dewasa obesitas. Berikut rumus perhitungan yang digunakan:

$$
\Sigma \mathrm{n}_{\text {kor }}=\Sigma \mathrm{nx} \mathrm{f}_{\text {(cor) }}
$$

Keterangan:

$\mathrm{Sn}_{\text {kor }}=$ Jumlah balita obesitas yang diprediksi obesitas saat dewasa

Sn = Jumlah balita obesitas menurut umur dan jenis kelamin

$\mathrm{f}_{(\text {cor) }}=$ Faktor koreksi menurut umur dan jenis kelamin

Setelah memperoleh jumlah balita obesitas yang diprediksi obesitas saat dewasa, berikutnya adalah menghitung prevalensi balita obesitas yang diprediksi obesitas saat dewasa dengan perhitungan sebagai berikut:

$$
\operatorname{Prev}_{\mathrm{kor}}=\Sigma \mathrm{n}_{\mathrm{kor}}: \Sigma \mathrm{np}
$$

Keterangan:

Prev $_{\text {kor }}=$ Prevalensi balita obesitas yang diprediksi obesitas saat dewasa

$\mathrm{Sn}_{\mathrm{kor}}=$ Jumlah balita obesitas yang diprediksi obesitas saat dewasa

Snp = Jumlah balita obesitas (3-5 tahun) sebelum dikoreksi menurut jenis kelamin

Hasil prevalensi yang diperoleh dari rumus di atas, selanjutnya akan digunakan untuk mencari jumlah penduduk balita obesitas di setiap provinsi yang ada di Indonesia yang telah dikoreksi dengan menggunakan faktor koreksi. Di Indonesia, terdapat sekitar 23.994.200 balita laki-laki dan perempuan (14) dan setelah dikalikan dengan prevalensi balita obesitas yang diprediksi obesitas 
saat dewasa, maka diperoleh sekitar 2.976.176 jumlah balita obesitas yang diprediksi obesitas saat dewasa. Lebih lanjut, untuk menghitung nilai ekonomi biaya perawatan (rawat inap dan rawat jalan) pada balita obesitas yang ketika dewasa mengalami masalah obesitas menggunakan rumus perhitungan sebagai berikut (17):

$$
\mathrm{CPLb}=\Sigma \mathrm{n}_{(\mathrm{l}) /(\mathrm{p})} \times \operatorname{PKc} \times \operatorname{Rij}_{(\mathrm{l})(\mathrm{p})}
$$

Keterangan:

$$
\begin{aligned}
\mathrm{CPLb}= & \text { Nilai ekonomi produktivitas akibat biaya } \\
& \text { perawatan } \\
\mathrm{Sn}_{(\mathrm{l})}= & \text { Jumlah penduduk balita laki-laki obesitas yang } \\
& \text { diprediksi obesitas saat dewasa } \\
\mathrm{Sn}_{(\mathrm{p})}= & \text { Jumlah penduduk balita perempuan obesitas } \\
& \text { yang diprediksi obesitas saat dewasa } \\
\mathrm{PKc}= & \text { Proporsi kejadian komorbiditas pada populasi } \\
& \text { obesitas } \\
\mathrm{Rij}_{(\mathfrak{l})(\mathrm{p})}= & \text { Biaya perawatan (rawat inap dan jalan) laki- } \\
& \text { laki/perempuan } \\
\mathrm{Ri}_{(\mathrm{l})(\mathrm{p})}= & \begin{array}{l}
\text { Rerata biaya perawatan rawat inap pada laki- } \\
\text { laki dan perempuan }
\end{array} \\
\mathrm{Rj}_{(\mathrm{l})(\mathrm{p})}= & \text { Rerata biaya perawatan rawat jalan pada laki- } \\
& \text { laki dan perempuan }
\end{aligned}
$$

Data yang telah ada akan dimasukan ke dalam rumus di atas. Rerata biaya perawatan (rawat inap dan rawat jalan) yang dikeluarkan untuk kejadian komorbiditas diperoleh dari data rumah sakit pemerintah, rumah sakit swasta, dokter, dan puskesmas. Proporsi kejadian komorbiditas diperoleh dari beberapa PTM yaitu kanker, DM, hipertensi, jantung iskemik (ischemic heart disease), osteoartritis, dan stroke pada populasi obesitas. Penelitian ini menggunakan enam penyakit penyerta (komorbiditas) tersebut karena menurut penelitian sebelumnya oleh Pitayatienanan et al. di Thailand (17), penyakit-penyakit ini memiliki risiko lebih tinggi terhadap kesehatan dan umumnya terjadi pada masyarakat secara global.

\section{HASIL}

Masalahgizi di Indonesiasemakinmengkhawatirkan, terutama dengan adanya masalah obesitas pada balita yang merupakan sumber daya manusia (SDM) atau merupakan generasi penerus untuk melanjutkan pembangunan negara sebagai negara berkembang. Prevalensi balita gemuk (overweight dan obesitas) di Indonesia telah mencapai 11,9\% mendekati prevalensi di negara-negara maju. Pada Tabel 1 menunjukkan prevalensi dari balita obesitas yang diperoleh dari hasil olah data sekunder (5) oleh peneliti sebesar 7,7\% balita obesitas di Indonesia pada tahun 2013. Prevalensi ini merupakan prevalensi balita obesitas (bukan prevalensi balita obesitas yang diprediksi obesitas saat dewasa) dan prevalensi ini tidak termasuk prevalensi dari balita overweight di Indonesia.

Jumlah penduduk balita pada Tabel 1 merupakan jumlah penduduk balita obesitas yang diprediksi obesitas saat dewasa (sehingga berbeda antara jumlah dan persentase prevalensinya). Hal ini karena selain telah diketahui prevalensi balita gemuk di Indonesia dari laporan Riskesdas tahun 2013, penelitian ini lebih spesifik mengenai balita obesitas (Z-score $>3$ ). Beberapa provinsi yang memiliki prevalensi masalah obesitas yang tinggi dan di atas prevalensi nasional adalah Provinsi Lampung, Banten, Sumatera Selatan, Bengkulu, dan Papua. Provinsi dengan prevalensi masalah obesitas tertinggi yaitu Provinsi Lampung sebesar 16,2\% dan Provinsi Banten sebesar 14,5\% (4). Pada Tabel 1 juga menunjukkan nilai potensi kerugian ekonomi akibat biaya perawatan (rawat inap dan rawat jalan) karena masalah obesitas di Indonesia tahun 2013.

Besar rerata potensi ekonomi yang hilang karena biaya perawatan rumah sakit (rawat inap dan rawat jalan) akibat masalah obesitas dan PTM pada balita di 33 provinsi yang ada di Indonesia adalah Rp 109 miliar pada laki-laki sedangkan pada perempuan adalah Rp 260 miliar. Jadi dapat dikatakan rata-rata potensi ekonomi yang hilang di 33 provinsi di Indonesia sekitar Rp 109 miliar - Rp 260 miliar, jika nilai ini dilihat dalam persentase terhadap PDRB maka besar potensi ekonomi yang hilang akibat biaya perawatan kesehatan karena masalah obesitas yaitu sekitar $0,08-0,17 \%$ dari rerata PDRB provinsi-provinsi di Indonesia.

Secara nasional, besar potensi ekonomi yang hilang akibat obesitas pada balita karena biaya rawat inap dan rawat jalan ketika dewasa pada balita laki-laki sebesar Rp 3.492 miliar dan perempuan sebesar Rp 8.717 miliar. Jika nilai ini dilihat dalam persentase terhadap 
Brigitte Sarah Renyoet, dkk: Potensi kerugian ekonomi akibat biaya rawat inap dan rawat jalan pada balita yang mengalami obesitas

Tabel 1. Prevalensi dan potensi kerugian ekonomi akibat biaya rawat inap dan rawat jalan karena obesitas di Indonesia tahun 2013

\begin{tabular}{|c|c|c|c|c|c|c|}
\hline \multirow{2}{*}{ Provinsi } & \multirow{2}{*}{$\begin{array}{l}\text { Jumlah balita } \\
\text { obesitas* }\end{array}$} & \multirow{2}{*}{$\begin{array}{c}\text { Prevalensi } \\
\text { balita obesitas }(\%)^{* *}\end{array}$} & \multicolumn{2}{|c|}{$\begin{array}{c}\text { PKE }^{1} \\
\text { (miliar rupiah) }\end{array}$} & \multicolumn{2}{|c|}{$\%$ PDRB $^{2}$} \\
\hline & & & $\mathbf{L}^{3}$ & $\mathbf{P}^{4}$ & $\mathbf{L}$ & $\mathbf{P}$ \\
\hline Aceh & 70.241 & 6,2 & 92 & 278 & 0,10 & 0,31 \\
\hline Bali & 41.112 & 9,3 & 475 & 682 & 0,12 & 0,17 \\
\hline Kep. Bangka Belitung & 15.561 & 6,2 & 53 & 134 & 0,04 & 0,11 \\
\hline Banten & 148.486 & 8,9 & 107 & 161 & 0,03 & 0,05 \\
\hline Bengkulu & 23.090 & 10,1 & 63 & 161 & 0,09 & 0,22 \\
\hline DI Yogyakarta & 29.606 & 11,9 & 105 & 170 & 0,06 & 0,09 \\
\hline DKI Jakarta & 116.907 & 11,6 & 29 & 29 & 0,11 & 0,11 \\
\hline Gorontalo & 12.988 & 16,2 & 83 & 211 & 0,05 & 0,13 \\
\hline Jambi & 41.545 & 7,1 & 27 & 64 & 0,07 & 0,17 \\
\hline Jawa Barat & 530.875 & 6,1 & 38 & 87 & 0,04 & 0,09 \\
\hline Jawa Tengah & 348.276 & 9,3 & 204 & 455 & 0,02 & 0,04 \\
\hline Jawa Timur & 367.152 & 7,0 & 683 & 1.941 & 0,07 & 0,19 \\
\hline Kalimantan Barat & 61.232 & 7,8 & 411 & 1.612 & 0,07 & 0,29 \\
\hline Kalimantan Selatan & 53.510 & 5,2 & 72 & 53 & 0,11 & 0,08 \\
\hline Kalimantan Tengah & 28.011 & 7,2 & 270 & 537 & 0,02 & 0,05 \\
\hline Kalimantan Timur & 49.122 & 14,5 & 140 & 208 & 0,06 & 0,09 \\
\hline Kep. Riau & 27.290 & 8,1 & 104 & 158 & 0,11 & 0,17 \\
\hline Lampung & 101.583 & 5,0 & 38 & 164 & 0,07 & 0,29 \\
\hline Maluku & 24.831 & 4,9 & 35 & 100 & 0,09 & 0,25 \\
\hline Maluku Utara & 16.696 & 8,2 & 34 & 50 & 0,04 & 0,06 \\
\hline Nusa Tenggara Barat & 57.645 & 7,8 & 21 & 51 & 0,03 & 0,08 \\
\hline Nusa Tenggara Timur & 73.268 & 5,9 & 51 & 70 & 0,06 & 0,09 \\
\hline Papua & 42.147 & 7,4 & 35 & 64 & 0,01 & 0,02 \\
\hline Papua Barat & 11.417 & 6,6 & 41 & 92 & 0,08 & 0,17 \\
\hline Riau & 85.102 & 4,3 & 37 & 74 & 0,06 & 0,13 \\
\hline Sulawesi Barat & 16.582 & 4,4 & 126 & 517 & 0,07 & 0,28 \\
\hline Sulawesi Selatan & 103.794 & 7,3 & 67 & 204 & 0,16 & 0,50 \\
\hline Sulawesi Tengah & 36.882 & 4,2 & 14 & 60 & 0,12 & 0,51 \\
\hline Sulawesi Tenggara & 37.300 & 7,2 & 5 & 3 & 0,03 & 0,02 \\
\hline Sulawesi Utara & 25.073 & 7,7 & 13 & 31 & 0,10 & 0,23 \\
\hline Sumatera Selatan & 101.913 & 4,9 & 32 & 42 & 0,41 & 0,55 \\
\hline Sumatera Barat & 65.411 & 4,2 & 8 & 16 & 0,03 & 0,07 \\
\hline Sumatera Utara & 197.678 & 10,3 & 71 & 101 & 0,08 & 0,11 \\
\hline Indonesia & 2.976.176 & 7,7 & 3.492 & 8.717 & 0,04 & 0,10 \\
\hline
\end{tabular}

*Jumlah balita obesitas yang diprediksi obesitas saat dewasa; **Data sekunder (olah) Riskesdas 2013;

${ }^{1} \mathrm{PKE}=$ potensi kerugian ekonomi; ${ }^{2} \mathrm{PDRB}=$ produk domestik regional bruto atas dasar harga berlaku tanpa migas;

${ }^{3} \mathrm{~L}=$ laki-laki; ${ }^{4} \mathrm{P}=$ perempuan

PDB Indonesia maka besar potensi ekonomi yang hilang akibat biaya perawatan kesehatan karena obesitas secara nasional sebesar 0,04\% pada laki-laki dan perempuan mencapai 0,10\% dari total PDB Indonesia. Dengan demikian, secara nasional dapat dikatakan bahwa besar potensi ekonomi yang hilang akibat biaya perawatan kesehatan karena masalah obesitas pada balita sekitar Rp
3.492 miliar - Rp 8.717 miliar atau 0,04\% - 0,10\% dari total PDB Indonesia.

Rentang tertinggi kerugian karena rawat inap dan rawat jalan pada laki-laki dan perempuan adalah $\mathrm{Rp}$ 683 miliar - Rp 1.941 miliar di Provinsi Jawa Barat, dengan persentase kehilangan potensi ekonomi akibat penurunan produktivitas terhadap PDRB provinsinya 
sekitar 0,07\% - 0,19\% di Indonesia. Sementara, rentang terendah kerugian ekonomi karena rawat inap dan rawat jalan pada perempuan dan laki-laki sebesar Rp 3 miliar - Rp 5 miliar di Provinsi Sulawesi Barat, dengan persentase kehilangan potensi ekonomi akibat penurunan produktivitas terhadap PDRB provinsinya sekitar 0,02\% $-0,03 \%$ di Indonesia.

\section{BAHASAN}

Hasil analisis pada penelitian ini menunjukan prevalensi balita obesitas yang tinggi di Indonesia. Obesitas ini dianggap sebagai salah satu faktor yang dapat meningkatkan prevalensi hipertensi, intoleransi glukosa, dan penyakit jantung koroner (aterosklerosis) pada pasien dengan obesitas (7). Pada anak yang mengalami masalah obesitas serta kurangnya aktivitas fisik dan ruang gerak yang terbatas, dapat mengalami gangguan pernapasan dan komplikasi ortopedi/tulang (15). Tingginya risiko dari obesitas bagi kesehatan ini terutama karena obesitas saat ini tidak hanya ditemukan pada orang dewasa tetapi juga telah banyak ditemukan pada balita dan remaja yang semakin hari semakin meningkat jumlahnya.

Mengkonsumsi makanan manis dan tinggi lemak (pola makan) serta pola hidup yang kurang sehat menyebabkan balita gemuk yang berisiko menimbulkan banyak penyakit, antara lain gangguan penyakit hati, penyumbatan atau gangguan saluran pernapasan ketika tidur dengan gejala mengompol sampai mengorok, serta usia yang lebih pendek daripada generasi orang tuanya. Kemungkinan ini terlihat dari berbagai risiko penyakit yang lebih mudah menyerang anak-anak yang kegemukan seperti misalnya penyakit jantung dan pembuluh darah, gangguan metabolisme glukosa, serta gangguan kulit (15). Obesitas pada anak akan menjadi masalah karena 15\% anak dengan kegemukan akan berlanjut ke masa dewasa. Menurut WHO, hasil penelitian di Jepang menunjukkan satu dari tiga anak obesitas akan tumbuh menjadi orang dewasa yang juga obesitas (19).

Rerata biaya rawat inap dan rawat jalan yang dikeluarkan untuk kejadian komorbiditas diperoleh dari data rumah sakit pemerintah, rumah sakit swasta, dokter, dan puskesmas. Data rawat inap dan rawat jalan setiap penyakit penyerta (orang/tahun) pada tahun 2013 diperoleh dari
Riskesdas tahun 2013 untuk seluruh provinsi di Indonesia. Rerata biaya ini diperoleh dari biaya yang dikeluarkan karena enam penyakit penyerta (komorbiditas) dengan menggunakan asumsi bahwa penyakit penyerta tersebut terjadi sebagai hasil paparan dari obesitas. Data biaya perawatan kesehatan pada penelitian ini merupakan biaya rawat inap dan rawat jalan yang dikeluarkan pasien dengan enam penyakit penyerta, tanpa memperhatikan tingkat keparahan dari penyakit tersebut dan kelas perawatan kesehatan ataupun komponen biaya perawatannya. Namun, biaya tersebut dapat mewakili semua orang yang melakukan perawatan dari berbagai tingkat pendapatan pada provinsiprovinsi di Indonesia karena biaya yang dikeluarkan oleh semua orang ini merupakan pengeluaran dari setiap orang yang memiliki akses keuangan untuk kesehatan pada berbagai tingkat pendapatan.

Potensi kerugian ekonomi akibat produktivitas yang rendah menunjukan nilai potensi kerugian yang cukup besar bagi Indonesia. Terutama nilai kerugian ini diperoleh dari estimasi potensi kerugian balita obesitas yang memiliki probabilitas untuk tetap obesitas ketika dewasa sehingga hal ini harus segara mendapatkan perhatian khusus dari pemerintah selain masalah gizi lainnya seperti kekurangan gizi yang terjadi di Indonesia. Transisi epidemiologi dan demografi peningkatan gizi lebih dan obesitas mulai terlihat seiring dengan masalah kekurangan gizi yang masih tinggi, terutama masalah obesitas ini terjadi bukan hanya pada orang dewasa tetapi telah dialami oleh balita. Masalah obesitas pada anak meningkat dari tahun ke tahun, baik di negara maju maupun negara yang sedang berkembang. Menurut WHO, diperkirakan 44 juta dari anak balita mengalami kelebihan berat badan atau obesitas di seluruh dunia (2).

Kerugian ekonomi akibat obesitas di negara lain seperti di Eropa yang memiliki biaya perawatan obesitas menggunakan anggaran perawatan kesehatan nasional sebesar \$269 juta atau sekitar 2,3\% dari total biaya perawatan rumah sakit di Swedia (20). Penelitian lainnya di Thailand mengenai kerugian ekonomi akibat biaya perawatan mencapai 5.584 juta baht (17). Tinggi dan rendahnya potensi kerugian ekonomi akibat biaya perawatan kesehatan di 33 provinsi yang ada di Indonesia, tidak selalu dapat dikatakan karena tingginya prevalensi obesitas di wilayah tersebut akan tetapi dapat dikarenakan 
perubahan pola penyakit. Jika dahulu banyak ditemukan berbagai penyakit yang bersifat akut, maka saat ini telah ditemukan berbagai penyakit yang bersifat kronis dan perawatan penyakit kronis membutuhkan waktu yang lebih lama. Akibatnya, biaya yang dikeluarkan untuk perawatan dan penyembuhan akan lebih banyak sehingga biaya kesehatan akan meningkat. Hal lain yang dapat mempengaruhi yaitu jumlah penduduk dan biaya perawatan untuk rawat inap dan rawat jalan dari beberapa penyakit komorbiditas dari obesitas yang lebih tinggi dari beberapa provinsi lain. Kenaikan biaya di berbagai negara berbeda-beda karena dipengaruhi oleh berbagai faktor, salah satunya adalah perubahan pola pelayanan kesehatan seperti perkembangan spesialisasi dan dokter umum. Menurut hasil penelitian sebelumnya (21), jika rumah sakit mempergunakan dokter umum, maka rumah sakit tersebut akan berhasil menghemat sekitar US\$39.00/tahun per dokter umum jika dibandingkan mempergunakan dokter spesialis (22). Penelitian ini membahas mengenai kerugian ekonomi akibat biaya rawat inap dan rawat jalan karena obesitas, untuk menunjukkan potensi besarnya dampak kerugian ekonomi yang diberikan karena masalah obesitas bagi individu dan negara.

\section{SIMPULAN DAN SARAN}

Secara nasional, besar potensi kerugian ekonomi akibat biaya rawat inap dan rawat jalan karena obesitas pada balita secara nasional sekitar Rp 3.492 miliar Rp 8.717 miliar atau 0,04\% - 0,10\% dari total PDB Indonesia. Rentang tertinggi kerugian karena rawat inap dan rawat jalan pada laki-laki dan perempuan ditemukan di Provinsi Jawa Barat dengan persentase terhadap PDRB provinsinya sekitar 0,07\% - 0,19\% di Indonesia. Penelitian lanjutan diharapkan menggunakan data panel pada balita obesitas agar hasilnya dapat tergambar secara jelas dan lebih rinci serta akurat.

\section{UCAPAN TERIMA KASIH}

Penulis menyampaikan terima kasih kepada Susan E. Horton, Ph.D yang telah banyak membantu baik dalam pemberian saran maupun referensi bagi penulis. Penulis juga menyampaikan terimakasih kepada Badan Penelitian dan Pengembangan Kesehatan, Badan Pusat Statistik, dan Kementerian Kesehatan RI yang telah membantu dalam penyediaan data penelitian.

\section{Pernyataan konflik kepentingan}

Tidak ada konflik kepentingan yang menyangkut finansial, personal, atau hubungan lainnya dengan pihakpihak yang terkait dalam penelitian ini.

\section{RUJUKAN}

1. Shrimpton R, Rokx C, Elder L, Marzoeki P, Dorkin D, Pambudi E, et al. United Nations Children's Fund, DeRuiter D, Kapoor M. Indonesia health sector review: menghadapi beban ganda malnutrisi. [series online] 2012 [cited 2015 Oktober 21]. Available from: URL: http:// mca-indonesia.go.id.

2. World Health Organization.World health statistics 2014. Geneva: WHO; 2014.

3. Dobbs R, Sawers C, Thompson F, Manyika J, Woetzel J, Spatharou A, et al. Overcoming obesity: an initial economic analysis. UK: The McKinsey Global Institute (MGI); 2014.

4. World Health Organization. Comprehensive plan on maternal, infant and young child nutrition. [series online] 2014 [cited 2015 Oktober 11]. Available from: URL: http:// www.who.int/media centre/factsheets/fs311/en/

5. Badan Penelitian dan Pengembangan Kesehatan. Laporan hasil riset kesehatan dasar Indonesia Tahun 2013. Jakarta: Kementerian Kesehatan Republik Indonesia; 2013.

6. Adiwinanto W. Pengaruh intervensi olahraga di sekolah terhadap indeks massa tubuh dan tingkat kebugaran kardiorespirasi pada remaja obesitas [Skripsi]. Semarang: Universitas Diponegoro; 2008.

7. American Heart Association. Heart international cardiovascular disease statistic. [series online] 2011 [cited 2015 Oktober 12]. Available from: URL: http://www. american heart.org/

8. Sihadi, Djaiman SPH. Risiko kegemukan terhadap kadar kolesterol. Media Gizi dan Keluarga 2006;30(1):58-64.

9. Blouin C. The economic impact of obesity and overweight. Quebec: Institut national de santé publique du Québec. [series online] 2014 [cited 2015 Oktober 15]. Available from: URL: http://www.inspq.qc.ca/english/topo

10. Colagiuri S, Lee CMY, Colagiuri R, Magliano D, Shaw JE, Caterson ID, et al. The cost of overweight and obesity in Australia. Med J Aus 2010;192(5):260-4.

11. Cawley J, Meyerhoefer C. The medical care costs of obesity: an instrumental variables approach. J Health Econ 2012;31(1):219-30. 
12. Wang LY, Denniston M, Lee S, Galuska D, Lowry R. Long-term health and economic impact of preventing and reducing overweight and obesity in adolescence. J Adolesc Health 2010;46(5):467-73.

13. Reinhold T, Schultzendorff AV, Riemenschneider FM. Economic consequences of overweight and obesity in Asia-Pacific. European Journal of Integrative Medicine 2011;3(1):3-9.

14. Badan Pusat Statistik. Laporan Bulanan Data Sosial Ekonomi. Edisi 55 Desember 2014. Jakarta: Badan Pusat Statistik Republik Indonesia; 2014.

15. Kementerian Kesehatan Republik Indonesia. "InfoDATIN" situasi kesehatan anak balita di Indonesia. Jakarta: Pusat Data dan Informasi Kementerian Kesehatan RI; 2015.

16. Badan Pusat Statistik. Keadaan pekerja di Indonesia November 2013. Jakarta: Badan Pusat Statistik Republik Indonesia; 2013.

17. Pitayatienanan P, Butchon R, Yothasamut J, Aekplakorn W, Teerawattananon Y, Thavorncharoensap M, et al. Economic costs of obesity in Thailand: a retrospective cost-of illness study. BMC Health Serv Res 2014;14:146.

18. Guo SS, Wu W, Chumlea WC, Roche AF. Predicting overweight and obesity in adulthood from body mass index values in childhood and adolescence. Am J Clin Nutr 2002;76(3):653-8.

19. World Health Organization. Obesity: preventing and managing the global epidemic. Geneva: WHO Technical Report series; 2000.

20. Borg S, Persson U, Odegaard K, Berglund G, Nilsson JA, Nilsson PM. Obesity, survival, and hospital costsfindings from a screening project in Sweden. Value Health 2005;8(5):562-71.

21. Stefani DL. Pembiayaan kesehatan. [series online] 2013 [cited 2016 Juni 20]. Available from: URL: http:// delfistefani. wordpress.com/2013/06/19/makalahpembiayaan-kesehatan/

22. Sulastomo. Manajemen kesehatan. Jakarta: PT. Gramedia Pustaka Utama; 2007. 


\section{Erratum}

Renyoet BS, Martianto D, Iskandar D. Potensi kerugian ekonomi akibat biaya rawat inap dan rawat jalan pada balita yang mengalami obesitas sampai dewasa di Indonesia. Jurnal Gizi Klinik Indonesia 2016;13(2):43-50.

Perbaikan judul dikoreksi oleh penulis menjadi: Potensi kerugian ekonomi akibat biaya rawat inap dan rawat jalan pada balita obesitas yang diprediksi mengalami obesitas saat dewasa di Indonesia.

Terjadi kesalahan pada nama penulis ketiga, yang sebelumnya dilaporkan Dadang Iskandar dikoreksi menjadi Dadang Sukandar.

Kesalahan juga muncul pada ucapan terima kasih yang seharusnya ditambahkan kalimat ucapan terima kasih kepada Badan Penelitian dan Pengembangan Kesehatan, Badan Pusat Statistik, dan Kementerian Kesehatan RI yang telah membantu dalam penyediaan data penelitian.

doi: $10.22146 /$ ijen.22899

\section{Erratum}

Yee LP, Wah CS. Application of red pitaya powder as a natural food colourant in fruit pastille. Jurnal Gizi Klinik Indonesia 2017;13(3):111-120.

The author name was corrected to: Low Pinn Yee, Tan Chin Ping, Lim Pek Kui, Chan Sook Wah.

The corresponding author was corrected to: Chan Sook Wah, School of Biosciences, Taylor's University No 1, Jalan Taylor's 47500 Subang Jaya, Selangor, Malaysia, e-mail: sookwah.chan@taylors.edu.my

doi: $10.22146 /$ ijen. 17863

\section{Erratum}

Sutiari NK, Rimbawan, Kusharto CM, Ascobat P, Effendi AT. Kromium serum dan asupan mikromineral pada penyandang diabetes tipe 2. Jurnal Gizi Klinik Indonesia 2017;13(4):135-143.

Kalimat simpulan pada bagian abstract dikoreksi oleh penulis menjadi: Conclusion: The study showed that serum chromium in DMT2 patients is lower than nondiabetic. The magnesium intake among DMT2 is higher as compare to nondiabetic, while zinc and chromium intake are not different in both group dan abstrak dikoreksi menjadi: Simpulan: Kromium serum pada DMT2 lebih rendah daripada nilai kromium serum nondiabetes. Asupan magnesium pada penyandang DMT2 lebih tinggi dibandingkan dengan nondiabetes, sedangkan asupan zink dan kromium pada kedua kelompok tidak berbeda.

Kalimat pada simpulan dan saran dikoreksi menjadi:

Kromium serum DMT2 lebih rendah dibandingkan dengan nondiabetes. Jenis mineral magnesium, zink, dan kromium merupakan jenis mineral yang terkait dengan perbaikan kontrol glikemik dan resistensi insulin. Penyandang DMT2 mempunyai asupan magnesium yang lebih tinggi dibandingkan dengan asupan magnesium nondiabetes dan telah memenuhi kecukupan magnesium yang dianjurkan. Asupan zink dan kromium antara penyandang DMT2 dan nondiabetes tidak berbeda, meskipun sebagian besar penyandang DMT2 (87,5\%) mempunyai asupan zink yang cukup. Asupan kromium pada penyandang DMT2 dan nondiabetes tergolong kurang dari nilai kecukupan kromium yang dianjurkan.

Saran untuk penelitian lebih lanjut sebaiknya melakukan pengukuran mineral magnesium, zink, dan kromium pada urin dan serum untuk memberikan gambaran status mineral magnesium, zink, dan kromium pada penyandang DMT2 dan mungkin dapat menggambarkan nilai bioavailabilitas mineral serta melakukan studi eksplorasi pada mikronutrien lain (vitamin).

doi: $10.22146 / \mathrm{ijen} .18883$ 


\title{
Potensi kerugian ekonomi akibat biaya rawat inap dan rawat jalan pada balita yang mengalami obesitas sampai dewasa di Indonesia
}

Economic losses potential due to cost of inpatient and outpatient in toddlers who has experienced obesity in to adulthood in Indonesia

\author{
Brigitte Sarah Renyoet $^{1}$, Drajat Martianto ${ }^{1}$, Dadang Iskandar ${ }^{1}$
}

${ }^{1}$ Departemen Gizi Masyarakat, Fakultas Ekologi Manusia Institut Pertanian Bogor

\begin{abstract}
Background: Nutrition and balance food very important for pregnant women so that the growth and fetal development can be optimally. Children excess nutrients will be developed into a child obesity, if not be addressed urgently and left until the children become obese adults will lead to decrease productivity. Objective: To estimate the economic losses potential to obesity on the toddler when adults remain obesity and sick so that issued a maintenance costs (inpatient and outpatient). Method: This was an descriptive study with data processing of a variety of the relevant agencies as well as a secondary data in 2013. Data obtained is calculated using the formula derived from research Pitayatienanan et al. 2014 and correction factor of Guo et al. 2002. Results: Estimation of the economic losses potential due to low productivity is $3.492-8.717$ billion rupiah/year $(0,04-0,10 \%)$ of the total GDP in Indonesia. Conclusion: Economic losses potential due to cost of obesity in Indonesia shows the loss of high enough, especially for a developing countries. In addition to its prevalence of problems that high, loss also influenced by the changes disease patterns, maintenance of costs each disease comorbidities of obesity itself.
\end{abstract}

KEY WORDS: economic losses; toddler obesity; toddlers 0-59 months of age

\begin{abstract}
ABSTRAK
Latar belakang: Makanan bergizi dan seimbang sangat penting bagi ibu hamil sehingga pertumbuhan dan perkembangan janin dapat optimal. Anak kelebihan gizi akan berkembang menjadi anak obesitas jika tidak segera diatasi dan dibiarkan sampai anak menjadi dewasa obesitas yang akan menyebabkan penurunan produktivitas. Tujuan: Melakukan estimasi besar potensi kerugian ekonomi akibat obesitas pada balita yang ketika dewasa tetap obesitas dan sakit sehingga mengeluarkan biaya perawatan (rawat inap dan rawat jalan). Metode: Penelitian deskriptif dengan mengolah data dari berbagai instansi terkait serta merupakan data sekunder tahun 2013. Data yang diperoleh dihitung menggunakan rumus yang berasal dari penelitian Pitayatienanan et al. tahun 2014 dan faktor koreksi dari Guo et al. tahun 2002. Hasil: Potensi kerugian ekonomi secara nasional akibat produktivitas yang rendah mencapai Rp 3.492 miliar - Rp 8.717 miliar atau 0,04\% - 0,10\% dari total PDB Indonesia. Simpulan: Kerugian ekonomi akibat biaya perawatan karena obesitas di Indonesia menunjukan kerugian yang cukup tinggi, terutama untuk suatu negara yang sedang berkembang. Selain karena prevalensi masalah yang tinggi, kerugian juga dipengaruhi oleh perubahan pola penyakit dan biaya perawatan dari setiap penyakit komorbiditas dari obesitas itu sendiri.
\end{abstract}

KATA KUNCI: kerugian ekonomi; balita obesitas; balita usia 0-59 bulan

\section{PENDAHULUAN}

Menurut laporan Landscape Analysis Country Assessment (LACA) sebesar 28,5\% mengalami stunting, $25 \%$ populasi dunia mengalami kelebihan berat badan, $17 \%$ anak prasekolah kekurangan berat badan, dan $40 \%$ wanita usia subur menderita anemia (1). Saat ini, obesitas sudah dialami oleh anak-anak di bawah usia 5 tahun (balita). Pada tahun 2012, diperkirakan 44 juta (6,7\%) dari anak-anak balita mengalami kelebihan berat badan atau obesitas di seluruh dunia. Berdasarkan angka terbaru ini,

Korespondensi: Brigitte Sarah Renyoet, Departemen Gizi Masyarakat, Fakultas Ekologi Manusia Institut Pertanian Bogor, Jl. Lingkar Akademik, Kampus IPB Darmaga, Bogor 16680,e-mail: brigitte.sarah@yahoo.com 
prevalensi global anak kelebihan berat badan dan obesitas telah berkembang dari sekitar 5\% pada tahun 1990 menjadi 7\% pada tahun 2012 (2). Bahkan, lebih dari 2,1 miliar orang ( $\pm 30 \%$ dari total populasi dunia) mengalami kelebihan berat badan atau obesitas (3). Menurut World Health Organization (WHO), prevalensi obesitas pada anak di negara berkembang dan negara miskin telah mengalami peningkatan dalam 10 tahun terakhir. Pada tahun 2015, diperkirakan tingkat kegemukan pada negara-negara tersebut akan mencapai prevalensi $11 \%$, mendekati prevalensi di negara berpenghasilan menengah atas yang prevalensinya mencapai $12 \%$ (4).

Hal ini didukung oleh data Riset Kesehatan Dasar (Riskesdas) yang menunjukkan bahwa insiden balita gemuk pada tahun 2013 mencapai 11,9\%. Terdapat beberapa provinsi yang memiliki masalah balita gemuk di atas prevalensi nasional yaitu Lampung, Sumatera Selatan, Bengkulu, Papua, dan Riau (5). Angka kejadian obesitas meningkat dengan pesat akibat pola hidup tidak aktif. Energi yang digunakan untuk aktivitas fisik sehari-hari mulai berkurang seiring dengan adanya globalisasi dan akibat dari kemajuan teknologi. Aktivitas fisik yang minimal pada waktu luang seperti menonton televisi dan bermain video games pada anak-anak meningkatkan angka kejadian obesitas (6). Masalah obesitas ini dianggap sebagai salah satu faktor yang dapat meningkatkan prevalensi penyakit tidak menular (PTM) seperti hipertensi, intoleransi glukosa, dan penyakit jantung koroner (aterosklerosis) (7). Obesitas juga memicu peningkatan kadar kolesterol, stroke, dan diabetes mellitus (DM) (8).

Dampak ekonomi obesitas secara global termasuk ke dalam tiga besar masalah sosial akibat manusia itu sendiri yang menghabiskan produk domestik bruto (PDB) dunia sekitar \$2 triliun atau 2,8\%. Obesitas juga mempengaruhi perekonomian karena berkurangnya produktivitas. Di Inggris kerugian mencapai \$5 juta akibat penurunan produktivitas kerja (3). Di Kanada pada tahun 2006, tambahan biaya kesehatan akibat kelebihan berat badan dan obesitas diperkirakan mencapai $\$ 6$ miliar dan terdapat tambahan pula sebesar $\$ 5$ miliar dari kehilangan produktivitas (9). Di Amerika setiap tahun diperkirakan biaya pengobatan akibat obesitas pada orang dewasa mencapai rata-rata \$2741 (mengacu pada dollar
Amerika tahun 2005). Di Australia pada tahun 2005, biaya langsung akibat beban kelebihan berat badan dan obesitas mencapai \$21 miliar per tahun (10). Sementara secara nasional, biaya kesehatan akibat penyakit terkait obesitas pada orang dewasa mencapai \$2097 miliar per tahun (11).

Laporan model simulasi untuk proyek kesehatan dan kemungkinan konsekuensi ekonomi dalam dua dekade berikutnya dari kenaikan prevalensi masalah obesitas di Amerika Serikat dan Inggris, memproyeksikan sebesar 65 juta orang dewasa obesitas di Amerika Serikat dan 11 juta orang dewasa obesitas di Inggris pada tahun 2030, akibatnya menimbulkan tambahan $6-8,5$ juta kasus diabetes; 5,7-7,3 juta kasus penyakit jantung dan stroke; serta 492.000 - 669.000 kasus tambahan kanker. Biaya medis gabungan terkait dengan pengobatan penyakit ini dapat dicegah, diperkirakan meningkat sebesar $\$ 48$ - 66 miliar/tahun di Amerika Serikat dan 1,9-2 miliar pounds/tahun di Inggris pada tahun 2030 (12). Penelitian lain yang telah mengidentifikasi hasil dari 75 penelitian di seluruh dunia, 11 penelitian yang difokuskan pada kawasan Asia-Pasifik (Taiwan, Cina, Jepang, Australia, dan Selandia Baru). Studi mengenai perkiraan biaya perawatan kesehatan langsung yang berhubungan dengan obesitas ditemukan mulai dari 0,059\% menjadi 0,49\% dari PDB nasional. Biaya langsung tertinggi dihitung dan menunjukkan bahwa pengeluaran tahunan mungkin setinggi US\$ 7,4 miliar setahun di Cina. Proyeksi ini menyimpulkan bahwa belanja langsung dan tidak langsung yang dikeluarkan untuk obesitas dapat melebihi 4,1\% dari PDB suatu negara (13).

Indonesia termasuk salah satu negara berkembang yang sedang mengalami masalah obesitas pada balita. Obesitas meningkatkan risiko PTM sehingga akan mempengaruhi ekonomi individu, rumah tangga maupun negara. Masalah gizi dapat meningkatkan biaya perawatan yang dikeluarkan untuk mengobati penyakit, kematian dini yang tidak diharapkan, dan biaya produktivitas yang hilang karena sakit dan kondisi fisik seseorang. Berdasarkan penelitian-penelitian sebelumnya, masih sedikit penelitian mengenai analisis ekonomi yang dapat mengungkapkan kerugian ekonomi akibat masalah gizi khususnya masalah kelebihan gizi yang mengakibatkan obesitas pada balita di Indonesia. 
Berdasarkan pertimbangan tersebut, peneliti tertarik untuk melakukan penelitian ini dengan tujuan yaitu melakukan estimasi perhitungan kerugian ekonomi akibat biaya rawat inap dan rawat jalan karena masalah obesitas di Indonesia.

\section{BAHAN DAN METODE}

Penelitian ini merupakan penelitian deskriptif yang dilakukan dengan mengolah data dari berbagai instansi terkait serta seluruh data yang diperoleh merupakan data sekunder. Kegiatan penelitian dilakukan di Bogor, Jawa Barat dan dilaksanakan mulai bulan Desember 2015 sampai Maret 2016. Jenis data yang dikumpulkan adalah data sekunder yang diperoleh dari berbagai instansi terkait di Indonesia, seperti Badan Penelitian dan Pengembangan Kesehatan (Riskesdas 2013), Badan Pusat Statistik (BPS), Kementerian Kesehatan RI (Kemenkes RI), serta data lain juga diperoleh dari publikasi jurnal-jurnal internasional. Data yang dikumpulkan berupa karakteristik balita di Indonesia (umur, jenis kelamin, data status gizi atau z-score balita, jumlah balita 0-59 bulan yang obesitas) (5), karakteristik penduduk menurut provinsi (jumlah penduduk balita, jumlah kelahiran, jenis kelamin, dan kelompok umur) $(14,15)$, upah/gaji tenaga kerja (data upah/gaji/pendapatan bersih pekerja menurut provinsi dan lapangan pekerjaan utama) (16).

Penelitian ini tidak menggunakan ethical clearance karena data yang digunakan merupakan data sekunder yang diperoleh dari penelitian dan publikasi instansi lain. Data yang diperoleh akan diolah menggunakan program microsoft excel. Estimasi potensi ekonomi yang hilang akibat obesitas pada balita dengan menggunakan rumus Pitayatienanan et al. hasil penelitian di Thailand (17) sedangkan untuk menghitung jumlah serta prevalensi balita umur 3-5 tahun yang obesitas dengan menggunakan faktor koreksi yang berasal dari penelitian obesitas lainnya (18). Menghitung potensi kerugian ekonomi karena obesitas pada balita membutuhkan faktor koreksi karena tidak semua balita obesitas ketika dewasa nanti tetap mengalami masalah obesitas sehingga penelitian ini menggunakan faktor koreksi untuk menghitung peluang menjadi dewasa obesitas. Lebih lanjut, untuk memperoleh jumlah balita obesitas yang diprediksi obesitas saat dewasa, jumlah balita obesitas laki-laki dan perempuan usia 3-5 tahun (5) dikali dengan faktor koreksi dari persentase probabilitas balita obesitas laki-laki usia 3 , 4, dan 5 tahun yang akan menjadi dewasa obesitas yaitu sebesar $0,15 \% ; 0,14 \%$; dan $0,31 \%$. Sementara faktor koreksi untuk balita obesitas perempuan pada usia yang sama yaitu sebesar $0,24 \% ; 0,25 \%$; dan $0,37 \%$ akan menjadi dewasa obesitas. Berikut rumus perhitungan yang digunakan:

$$
\Sigma \mathrm{n}_{\text {kor }}=\Sigma \mathrm{n} \mathrm{x} \mathrm{f}_{\text {(cor) }}
$$

Keterangan:

$\mathrm{Sn}_{\text {kor }}=$ Jumlah balita obesitas yang diprediksi obesitas saat dewasa

$\mathrm{Sn}=$ Jumlah balita obesitas menurut umur dan jenis kelamin

$\mathrm{f}_{(\text {cor) }}=$ Faktor koreksi menurut umur dan jenis kelamin

Setelah memperoleh jumlah balita obesitas yang diprediksi obesitas saat dewasa, berikutnya adalah menghitung prevalensi balita obesitas yang diprediksi obesitas saat dewasa dengan perhitungan sebagai berikut:

$$
\operatorname{Prev}_{\mathrm{kor}}=\Sigma \mathrm{n}_{\mathrm{kor}}: \Sigma \mathrm{np}
$$

Keterangan:

Prev $_{\text {kor }}=$ Prevalensi balita obesitas yang diprediksi obesitas saat dewasa

$\mathrm{Sn}_{\text {kor }}=$ Jumlah balita obesitas yang diprediksi obesitas saat dewasa

Snp = Jumlah balita obesitas (3-5 tahun) sebelum dikoreksi menurut jenis kelamin

Hasil prevalensi yang diperoleh dari rumus di atas, selanjutnya akan digunakan untuk mencari jumlah penduduk balita obesitas di setiap provinsi yang ada di Indonesia yang telah dikoreksi dengan menggunakan faktor koreksi. Di Indonesia, terdapat sekitar 23.994.200 balita laki-laki dan perempuan (14) dan setelah dikalikan dengan prevalensi balita obesitas yang diprediksi obesitas saat dewasa, maka diperoleh sekitar 2.976.176 jumlah balita obesitas yang diprediksi obesitas saat dewasa. 
Lebih lanjut, untuk menghitung nilai ekonomi biaya perawatan (rawat inap dan rawat jalan) pada balita obesitas yang ketika dewasa mengalami masalah obesitas menggunakan rumus perhitungan sebagai berikut (17):

$$
\mathrm{CPLb}=\Sigma \mathrm{n}_{(\mathrm{l}) /(\mathrm{p})} \times \operatorname{PKc} \times \operatorname{Rij}_{(\mathrm{l}) /(\mathrm{p})}
$$

Keterangan:

$\mathrm{CPLb}=$ Nilai ekonomi produktivitas akibat biaya perawatan

$\mathrm{Sn}_{(1)}=$ Jumlah penduduk balita laki-laki obesitas yang diprediksi obesitas saat dewasa

$\mathrm{Sn}_{(\mathrm{p})} \quad=$ Jumlah penduduk balita perempuan obesitas yang diprediksi obesitas saat dewasa

$\mathrm{PKc}=$ Proporsi kejadian komorbiditas pada populasi obesitas

$\operatorname{Rij}_{(\mathfrak{I}) /(\mathrm{p})}=$ Biaya perawatan (rawat inap dan jalan) lakilaki/perempuan

$\mathrm{Ri}_{(1) /(\mathrm{p})}=$ Rerata biaya perawatan rawat inap pada lakilaki dan perempuan

$\mathrm{Rj}_{(\mathfrak{l})(\mathrm{p})}=$ Rerata biaya perawatan rawat jalan pada lakilaki dan perempuan

Data yang telah ada akan dimasukan ke dalam rumus di atas. Rerata biaya perawatan (rawat inap dan rawat jalan) yang dikeluarkan untuk kejadian komorbiditas diperoleh dari data rumah sakit pemerintah, rumah sakit swasta, dokter, dan puskesmas. Proporsi kejadian komorbiditas diperoleh dari beberapa PTM yaitu kanker, DM, hipertensi, jantung iskemik (ischemic heart disease), osteoartritis, dan stroke pada populasi obesitas. Penelitian ini menggunakan enam penyakit penyerta (komorbiditas) tersebut karena menurut penelitian sebelumnya oleh Pitayatienanan et al. di Thailand (17), penyakit-penyakit ini memiliki risiko lebih tinggi terhadap kesehatan dan umumnya terjadi pada masyarakat secara global.

\section{HASIL}

Masalah gizi di Indonesiasemakin mengkhawatirkan, terutama dengan adanya masalah obesitas pada balita yang merupakan sumber daya manusia (SDM) atau merupakan generasi penerus untuk melanjutkan pembangunan negara sebagai negara berkembang. Prevalensi balita gemuk (overweight dan obesitas) di Indonesia telah mencapai $11,9 \%$ mendekati prevalensi di negara-negara maju. Pada Tabel 1 menunjukkan prevalensi dari balita obesitas yang diperoleh dari hasil olah data sekunder (5) oleh peneliti sebesar $7,7 \%$ balita obesitas di Indonesia pada tahun 2013. Prevalensi ini merupakan prevalensi balita obesitas (bukan prevalensi balita obesitas yang diprediksi obesitas saat dewasa) dan prevalensi ini tidak termasuk prevalensi dari balita overweight di Indonesia.

Jumlah penduduk balita pada Tabel 1 merupakan jumlah penduduk balita obesitas yang diprediksi obesitas saat dewasa (sehingga berbeda antara jumlah dan persentase prevalensinya). Hal ini karena selain telah diketahui prevalensi balita gemuk di Indonesia dari laporan Riskesdas tahun 2013, penelitian ini lebih spesifik mengenai balita obesitas (Z-score $>3$ ). Beberapa provinsi yang memiliki prevalensi masalah obesitas yang tinggi dan di atas prevalensi nasional adalah Provinsi Lampung, Banten, Sumatera Selatan, Bengkulu, dan Papua. Provinsi dengan prevalensi masalah obesitas tertinggi yaitu Provinsi Lampung sebesar 16,2\% dan Provinsi Banten sebesar 14,5\% (4). Pada Tabel 1 juga menunjukkan nilai potensi kerugian ekonomi akibat biaya perawatan (rawat inap dan rawat jalan) karena masalah obesitas di Indonesia tahun 2013.

Besar rerata potensi ekonomi yang hilang karena biaya perawatan rumah sakit (rawat inap dan rawat jalan) akibat masalah obesitas dan PTM pada balita di 33 provinsi yang ada di Indonesia adalah Rp 109 miliar pada laki-laki sedangkan pada perempuan adalah Rp 260 miliar. Jadi dapat dikatakan rata-rata potensi ekonomi yang hilang di 33 provinsi di Indonesia sekitar Rp 109 miliar - Rp 260 miliar, jika nilai ini dilihat dalam persentase terhadap PDRB maka besar potensi ekonomi yang hilang akibat biaya perawatan kesehatan karena masalah obesitas yaitu sekitar $0,08-0,17 \%$ dari rerata PDRB provinsi-provinsi di Indonesia.

Secara nasional, besar potensi ekonomi yang hilang akibat obesitas pada balita karena biaya rawat inap dan rawat jalan ketika dewasa pada balita laki-laki sebesar Rp 3.492 miliar dan perempuan sebesar Rp 8.717 miliar. Jika nilai ini dilihat dalam persentase terhadap PDB Indonesia maka besar potensi ekonomi yang hilang akibat biaya perawatan kesehatan karena obesitas secara 
Tabel 1. Prevalensi dan potensi kerugian ekonomi akibat biaya rawat inap dan rawat jalan karena obesitas di Indonesia tahun 2013

\begin{tabular}{|c|c|c|c|c|c|c|}
\hline \multirow{2}{*}{ Provinsi } & \multirow{2}{*}{$\begin{array}{c}\text { Jumlah balita } \\
\text { obesitas* }\end{array}$} & \multirow{2}{*}{$\begin{array}{c}\text { Prevalensi } \\
\text { balita obesitas }(\%)^{* *}\end{array}$} & \multicolumn{2}{|c|}{$\begin{array}{c}\text { PKE }^{1} \\
\text { (miliar rupiah) }\end{array}$} & \multicolumn{2}{|c|}{$\%$ PDRB $^{2}$} \\
\hline & & & $\mathbf{L}^{3}$ & $\mathbf{P}^{4}$ & $\mathbf{L}$ & $\mathbf{P}$ \\
\hline Aceh & 70.241 & 6,2 & 92 & 278 & 0,10 & 0,31 \\
\hline Bali & 41.112 & 9,3 & 475 & 682 & 0,12 & 0,17 \\
\hline Kep. Bangka Belitung & 15.561 & 6,2 & 53 & 134 & 0,04 & 0,11 \\
\hline Banten & 148.486 & 8,9 & 107 & 161 & 0,03 & 0,05 \\
\hline Bengkulu & 23.090 & 10,1 & 63 & 161 & 0,09 & 0,22 \\
\hline DI Yogyakarta & 29.606 & 11,9 & 105 & 170 & 0,06 & 0,09 \\
\hline DKI Jakarta & 116.907 & 11,6 & 29 & 29 & 0,11 & 0,11 \\
\hline Gorontalo & 12.988 & 16,2 & 83 & 211 & 0,05 & 0,13 \\
\hline Jambi & 41.545 & 7,1 & 27 & 64 & 0,07 & 0,17 \\
\hline Jawa Barat & 530.875 & 6,1 & 38 & 87 & 0,04 & 0,09 \\
\hline Jawa Tengah & 348.276 & 9,3 & 204 & 455 & 0,02 & 0,04 \\
\hline Jawa Timur & 367.152 & 7,0 & 683 & 1.941 & 0,07 & 0,19 \\
\hline Kalimantan Barat & 61.232 & 7,8 & 411 & 1.612 & 0,07 & 0,29 \\
\hline Kalimantan Selatan & 53.510 & 5,2 & 72 & 53 & 0,11 & 0,08 \\
\hline Kalimantan Tengah & 28.011 & 7,2 & 270 & 537 & 0,02 & 0,05 \\
\hline Kalimantan Timur & 49.122 & 14,5 & 140 & 208 & 0,06 & 0,09 \\
\hline Kep. Riau & 27.290 & 8,1 & 104 & 158 & 0,11 & 0,17 \\
\hline Lampung & 101.583 & 5,0 & 38 & 164 & 0,07 & 0,29 \\
\hline Maluku & 24.831 & 4,9 & 35 & 100 & 0,09 & 0,25 \\
\hline Maluku Utara & 16.696 & 8,2 & 34 & 50 & 0,04 & 0,06 \\
\hline Nusa Tenggara Barat & 57.645 & 7,8 & 21 & 51 & 0,03 & 0,08 \\
\hline Nusa Tenggara Timur & 73.268 & 5,9 & 51 & 70 & 0,06 & 0,09 \\
\hline Papua & 42.147 & 7,4 & 35 & 64 & 0,01 & 0,02 \\
\hline Papua Barat & 11.417 & 6,6 & 41 & 92 & 0,08 & 0,17 \\
\hline Riau & 85.102 & 4,3 & 37 & 74 & 0,06 & 0,13 \\
\hline Sulawesi Barat & 16.582 & 4,4 & 126 & 517 & 0,07 & 0,28 \\
\hline Sulawesi Selatan & 103.794 & 7,3 & 67 & 204 & 0,16 & 0,50 \\
\hline Sulawesi Tengah & 36.882 & 4,2 & 14 & 60 & 0,12 & 0,51 \\
\hline Sulawesi Tenggara & 37.300 & 7,2 & 5 & 3 & 0,03 & 0,02 \\
\hline Sulawesi Utara & 25.073 & 7,7 & 13 & 31 & 0,10 & 0,23 \\
\hline Sumatera Selatan & 101.913 & 4,9 & 32 & 42 & 0,41 & 0,55 \\
\hline Sumatera Barat & 65.411 & 4,2 & 8 & 16 & 0,03 & 0,07 \\
\hline Sumatera Utara & 197.678 & 10,3 & 71 & 101 & 0,08 & 0,11 \\
\hline Indonesia & 2.976 .176 & 7,7 & 3.492 & 8.717 & 0,04 & 0,10 \\
\hline
\end{tabular}

*Jumlah balita obesitas yang diprediksi obesitas saat dewasa; **Data sekunder (olah) Riskesdas 2013;

${ }^{1} \mathrm{PKE}=$ potensi kerugian ekonomi; ${ }^{2} \mathrm{PDRB}=$ produk domestik regional bruto atas dasar harga berlaku tanpa migas;

${ }^{3} \mathrm{~L}=$ laki-laki; ${ }^{4} \mathrm{P}=$ perempuan

nasional sebesar $0,04 \%$ pada laki-laki dan perempuan mencapai $0,10 \%$ dari total PDB Indonesia. Dengan demikian, secara nasional dapat dikatakan bahwa besar potensi ekonomi yang hilang akibat biaya perawatan kesehatan karena masalah obesitas pada balita sekitar Rp 3.492 miliar - Rp 8.717 miliar atau $0,04 \%$ - 0,10\% dari total PDB Indonesia.
Rentang tertinggi kerugian karena rawat inap dan rawat jalan pada laki-laki dan perempuan adalah $\mathrm{Rp}$ 683 miliar - Rp 1.941 miliar di Provinsi Jawa Barat, dengan persentase kehilangan potensi ekonomi akibat penurunan produktivitas terhadap PDRB provinsinya sekitar $0,07 \%-0,19 \%$ di Indonesia. Sementara, rentang terendah kerugian ekonomi karena rawat inap dan 
rawat jalan pada perempuan dan laki-laki sebesar Rp 3 miliar - Rp 5 miliar di Provinsi Sulawesi Barat, dengan persentase kehilangan potensi ekonomi akibat penurunan produktivitas terhadap PDRB provinsinya sekitar $0,02 \%$ $-0,03 \%$ di Indonesia.

\section{BAHASAN}

Hasil analisis pada penelitian ini menunjukan prevalensi balita obesitas yang tinggi di Indonesia. Obesitas ini dianggap sebagai salah satu faktor yang dapat meningkatkan prevalensi hipertensi, intoleransi glukosa, dan penyakit jantung koroner (aterosklerosis) pada pasien dengan obesitas (7). Pada anak yang mengalami masalah obesitas serta kurangnya aktivitas fisik dan ruang gerak yang terbatas, dapat mengalami gangguan pernapasan dan komplikasi ortopedi/tulang (15). Tingginya risiko dari obesitas bagi kesehatan ini terutama karena obesitas saat ini tidak hanya ditemukan pada orang dewasa tetapi juga telah banyak ditemukan pada balita dan remaja yang semakin hari semakin meningkat jumlahnya.

Mengkonsumsi makanan manis dan tinggi lemak (pola makan) serta pola hidup yang kurang sehat menyebabkan balita gemuk yang berisiko menimbulkan banyak penyakit, antara lain gangguan penyakit hati, penyumbatan atau gangguan saluran pernapasan ketika tidur dengan gejala mengompol sampai mengorok, serta usia yang lebih pendek daripada generasi orang tuanya. Kemungkinan ini terlihat dari berbagai risiko penyakit yang lebih mudah menyerang anak-anak yang kegemukan seperti misalnya penyakit jantung dan pembuluh darah, gangguan metabolisme glukosa, serta gangguan kulit (15). Obesitas pada anak akan menjadi masalah karena $15 \%$ anak dengan kegemukan akan berlanjut ke masa dewasa. Menurut WHO, hasil penelitian di Jepang menunjukkan satu dari tiga anak obesitas akan tumbuh menjadi orang dewasa yang juga obesitas (19).

Rerata biaya rawat inap dan rawat jalan yang dikeluarkan untuk kejadian komorbiditas diperoleh dari data rumah sakit pemerintah, rumah sakit swasta, dokter, dan puskesmas. Data rawat inap dan rawat jalan setiap penyakit penyerta (orang/tahun) pada tahun 2013 diperoleh dari Riskesdas tahun 2013 untuk seluruh provinsi di Indonesia. Rerata biaya ini diperoleh dari biaya yang dikeluarkan karena enam penyakit penyerta (komorbiditas) dengan menggunakan asumsi bahwa penyakit penyerta tersebut terjadi sebagai hasil paparan dari obesitas. Data biaya perawatan kesehatan pada penelitian ini merupakan biaya rawat inap dan rawat jalan yang dikeluarkan pasien dengan enam penyakit penyerta, tanpa memperhatikan tingkat keparahan dari penyakit tersebut dan kelas perawatan kesehatan ataupun komponen biaya perawatannya. Namun, biaya tersebut dapat mewakili semua orang yang melakukan perawatan dari berbagai tingkat pendapatan pada provinsi-provinsi di Indonesia karena biaya yang dikeluarkan oleh semua orang ini merupakan pengeluaran dari setiap orang yang memiliki akses keuangan untuk kesehatan pada berbagai tingkat pendapatan.

Potensi kerugian ekonomi akibat produktivitas yang rendah menunjukan nilai potensi kerugian yang cukup besar bagi Indonesia. Terutama nilai kerugian ini diperoleh dari estimasi potensi kerugian balita obesitas yang memiliki probabilitas untuk tetap obesitas ketika dewasa sehingga hal ini harus segara mendapatkan perhatian khusus dari pemerintah selain masalah gizi lainnya seperti kekurangan gizi yang terjadi di Indonesia. Transisi epidemiologi dan demografi peningkatan gizi lebih dan obesitas mulai terlihat seiring dengan masalah kekurangan gizi yang masih tinggi, terutama masalah obesitas ini terjadi bukan hanya pada orang dewasa tetapi telah dialami oleh balita. Masalah obesitas pada anak meningkat dari tahun ke tahun, baik di negara maju maupun negara yang sedang berkembang. Menurut WHO, diperkirakan 44 juta dari anak balita mengalami kelebihan berat badan atau obesitas di seluruh dunia (2).

Kerugian ekonomi akibat obesitas di negara lain seperti di Eropa yang memiliki biaya perawatan obesitas menggunakan anggaran perawatan kesehatan nasional sebesar \$269 juta atau sekitar 2,3\% dari total biaya perawatan rumah sakit di Swedia (20). Penelitian lainnya di Thailand mengenai kerugian ekonomi akibat biaya perawatan mencapai 5.584 juta baht (17). Tinggi dan rendahnya potensi kerugian ekonomi akibat biaya perawatan kesehatan di 33 provinsi yang ada di Indonesia, tidak selalu dapat dikatakan karena tingginya prevalensi obesitas di wilayah tersebut akan tetapi dapat dikarenakan perubahan pola penyakit. Jika dahulu banyak ditemukan 
berbagai penyakit yang bersifat akut, maka saat ini telah ditemukan berbagai penyakit yang bersifat kronis dan perawatan penyakit kronis membutuhkan waktu yang lebih lama. Akibatnya, biaya yang dikeluarkan untuk perawatan dan penyembuhan akan lebih banyak sehingga biaya kesehatan akan meningkat. Hal lain yang dapat mempengaruhi yaitu jumlah penduduk dan biaya perawatan untuk rawat inap dan rawat jalan dari beberapa penyakit komorbiditas dari obesitas yang lebih tinggi dari beberapa provinsi lain. Kenaikan biaya di berbagai negara berbeda-beda karena dipengaruhi oleh berbagai faktor, salah satunya adalah perubahan pola pelayanan kesehatan seperti perkembangan spesialisasi dan dokter umum. Menurut hasil penelitian sebelumnya (21), jika rumah sakit mempergunakan dokter umum, maka rumah sakit tersebut akan berhasil menghemat sekitar US\$39.00/tahun per dokter umum jika dibandingkan mempergunakan dokter spesialis (22). Penelitian ini membahas mengenai kerugian ekonomi akibat biaya rawat inap dan rawat jalan karena obesitas, untuk menunjukkan potensi besarnya dampak kerugian ekonomi yang diberikan karena masalah obesitas bagi individu dan negara.

\section{SIMPULAN DAN SARAN}

Secara nasional, besar potensi kerugian ekonomi akibat biaya rawat inap dan rawat jalan karena obesitas pada balita secara nasional sekitar Rp 3.492 miliar Rp 8.717 miliar atau $0,04 \%$ - 0,10\% dari total PDB Indonesia. Rentang tertinggi kerugian karena rawat inap dan rawat jalan pada laki-laki dan perempuan ditemukan di Provinsi Jawa Barat dengan persentase terhadap PDRB provinsinya sekitar 0,07\% - 0,19\% di Indonesia. Penelitian lanjutan diharapkan menggunakan data panel pada balita obesitas agar hasilnya dapat tergambar secara jelas dan lebih rinci serta akurat.

\section{UCAPAN TERIMA KASIH}

Penulis menyampaikan terima kasih kepada Susan E. Horton, Ph.D yang telah banyak membantu baik dalam pemberian saran maupun referensi bagi penulis.

\section{Pernyataan konflik kepentingan}

Tidak ada konflik kepentingan yang menyangkut finansial, personal, atau hubungan lainnya dengan pihakpihak yang terkait dalam penelitian ini.

\section{RUJUKAN}

1. Shrimpton R, Rokx C, Elder L, Marzoeki P, Dorkin D, Pambudi E, et al. United Nations Children's Fund, DeRuiter D, Kapoor M. Indonesia health sector review: menghadapi beban ganda malnutrisi. [series online] 2012 [cited 2015 Oktober 21]. Available from: URL: http:// mca-indonesia.go.id.

2. World Health Organization.World health statistics 2014. Geneva: WHO; 2014.

3. Dobbs R, Sawers C, Thompson F, Manyika J, Woetzel J, Spatharou A, et al. Overcoming obesity: an initial economic analysis. UK: The McKinsey Global Institute (MGI); 2014.

4. World Health Organization. Comprehensive plan on maternal, infant and young child nutrition. [series online] 2014 [cited 2015 Oktober 11]. Available from: URL: http:// www.who.int/media centre/factsheets/fs311/en/

5. Badan Penelitian dan Pengembangan Kesehatan. Laporan hasil riset kesehatan dasar Indonesia Tahun 2013. Jakarta: Kementerian Kesehatan Republik Indonesia; 2013.

6. Adiwinanto W. Pengaruh intervensi olahraga di sekolah terhadap indeks massa tubuh dan tingkat kebugaran kardiorespirasi pada remaja obesitas [Skripsi]. Semarang: Universitas Diponegoro; 2008.

7. American Heart Association. Heart international cardiovascular disease statistic. [series online] 2011 [cited 2015 Oktober 12]. Available from: URL: http://www. american heart.org/

8. Sihadi, Djaiman SPH. Risiko kegemukan terhadap kadar kolesterol. Media Gizi dan Keluarga 2006;30(1):58-64.

9. Blouin C. The economic impact of obesity and overweight. Quebec: Institut national de santé publique du Québec. [series online] 2014 [cited 2015 Oktober 15]. Available from: URL: http://www.inspq.qc.ca/english/topo

10. Colagiuri S, Lee CMY, Colagiuri R, Magliano D, Shaw JE, Caterson ID, et al. The cost of overweight and obesity in Australia. Med J Aus 2010;192(5):260-4.

11. Cawley J, Meyerhoefer C. The medical care costs of obesity: an instrumental variables approach. J Health Econ 2012;31(1):219-30.

12. Wang LY, Denniston M, Lee S, Galuska D, Lowry R. Long-term health and economic impact of preventing and 
reducing overweight and obesity in adolescence. J Adolesc Health 2010;46(5):467-73.

13. Reinhold T, Schultzendorff AV, Riemenschneider FM. Economic consequences of overweight and obesity in Asia-Pacific. European Journal of Integrative Medicine 2011;3(1):3-9.

14. Badan Pusat Statistik. Laporan Bulanan Data Sosial Ekonomi. Edisi 55 Desember 2014. Jakarta: Badan Pusat Statistik Republik Indonesia; 2014.

15. Kementerian Kesehatan Republik Indonesia. "InfoDATIN" situasi kesehatan anak balita di Indonesia. Jakarta: Pusat Data dan Informasi Kementerian Kesehatan RI; 2015.

16. Badan Pusat Statistik. Keadaan pekerja di Indonesia November 2013. Jakarta: Badan Pusat Statistik Republik Indonesia; 2013.

17. Pitayatienanan $P$, Butchon R, Yothasamut J, Aekplakorn W, Teerawattananon Y, Thavorncharoensap M, et al. Economic costs of obesity in Thailand: a retrospective cost-of illness study. BMC Health Serv Res 2014;14:146.
18. Guo SS, Wu W, Chumlea WC, Roche AF. Predicting overweight and obesity in adulthood from body mass index values in childhood and adolescence. Am J Clin Nutr 2002;76(3):653-8.

19. World Health Organization. Obesity: preventing and managing the global epidemic. Geneva: WHO Technical Report series; 2000.

20. Borg S, Persson U, Odegaard K, Berglund G, Nilsson JA, Nilsson PM. Obesity, survival, and hospital costsfindings from a screening project in Sweden. Value Health 2005;8(5):562-71.

21. Stefani DL. Pembiayaan kesehatan. [series online] 2013 [cited 2016 Juni 20]. Available from: URL: http:// delfistefani. wordpress.com/2013/06/19/makalahpembiayaan-kesehatan/

22. Sulastomo. Manajemen kesehatan. Jakarta: PT. Gramedia Pustaka Utama; 2007. 